\title{
The protein dispersibility index in the quality control of heat-treated full-fat soybeans: an inter-laboratory study
}

\author{
D. Palić ${ }^{1 \#}$, K.Y. Modika ${ }^{2}$, A. Oelofse ${ }^{3}$, L. Morey $^{2}$ \& S.E. Coetzee ${ }^{2}$ \\ ${ }^{1}$ Institute of Food Technology, University of Novi Sad, Bulevar cara Lazara 1, 21000 Novi Sad, Serbia \\ ${ }^{2}$ Agricultural Research Council, Private Bag X2, Irene, 0062, South Africa \\ ${ }^{3}$ Centre for Nutrition, Faculty of Natural \& Agricultural Sciences, University of Pretoria, 0002, South Africa
}
Copyright resides with the authors in terms of the Creative Commons Attribution 2.5 South African Licence.
See: http://creativecommons.org/licenses/by/2.5/za
Condition of use: The user may copy, distribute, transmit and adapt the work, but must recognise the authors and the South African Journal of Animal Science.

\begin{abstract}
There are a number of laboratory methods that could be used to estimate the adequacy of full-fat soybean (FFSB) heat treatment. The protein despersibility index (PDI) has been claimed to have the most constant response to the heating of FFSBs. In this study, the PDI method has been subjected to an interlaboratory test, including the participation of eight laboratories. Seven FFSB samples were processed by dry extrusion at temperatures ranging from 110 to $164{ }^{\circ} \mathrm{C}$ and analysed on the PDI. Processed FFSB samples were also assessed in a growth trial of broilers. The analysis of the FFSBs by the PDI method generated adequately-processed FFSB values of between $8.49 \%$ and $10.3 \%$. Values above $10.3 \%$ described underprocessed and below $8.49 \%$ over-processed FFSBs. The PDI method generated a good repeatability limit of $2.1 \%$, but the reproducibility limit $(7.73 \%)$ was too wide when taking into account the narrow range $(8.5-$ $10.3 \%$ ) for adequately heat-treated FFSBs. Despite its simplicity and initial indications that it might be the best indicator of FFSB heat treatment, the PDI method did not prove that in this inter-laboratory study.
\end{abstract}

Keywords: Broilers, processing, extrusion, repeatability, reproducibility

${ }^{\#}$ Corresponding author: dragan.palic@fins.uns.ac.rs

\section{Introduction}

Soybeans contain highly valuable proteins and oils (crude protein ranging from $390-410 \mathrm{~g} / \mathrm{kg}$ and oil from $180-210 \mathrm{~g} / \mathrm{kg}$ ) which make them good feed alternatives to animal proteins and oils. Raw soybeans contain several factors with anti-nutritional properties and must be processed prior to inclusion in animal diets. The anti-nutritional factors (ANFs) contained in soybeans may cause unfavourable physiological effects (Buttle et al., 2001; Vasconcelos et al., 2001) and may decrease weight gain in animals (Palacios et al., 2004). The processing of raw full-fat soybeans (FFSB) by means of heat and mechanical treatment destroys the anti-nutrients, thus making the soybean fit for use in monogastric diets. The problem relating to availability of the amino acids in the heat-treated soybeans arises due to the fact that only an optimum level of heat treatment will produce the maximum availability of the amino acids to the animal. The underprocessing of the FFSBs limits amino acid availability due to the partial destruction of the anti-nutritional factors. Over-processing, on the other hand, decreases the amino acid availability as a result of the Maillard reaction that occurs between aldehyde groups of sugar and free amino groups (Vohra \& Kratzer, 1991).

There are a number of laboratory methods that could be used to estimate the adequacy of FFSB heat treatment. Commonly-used methods for assessing the processed FFSB quality are those that determine the urease activity index (UAI), trypsin inhibitor activity (TIA), nitrogen solubility index (NSI), protein dispersibility index (PDI) and protein solubility in potassium hydroxide (PSKOH) (Monary, 1989).

It has been clearly illustrated that the results of the analysis of the same sample of FFSBs obtained by currently available analytical techniques, vary widely between laboratories, causing uncertainty and confusion among soya processors, feed manufacturers and end-users (Davies, 1998; Palic \& Grove, 2004; Palić, 2011). It is, therefore, of the utmost importance that the available laboratory procedures be standardized for determining the degree of soybean processing. 
In a critical assessment of methods, Palic et al. (2007) concluded that protein solubility was the most reliable indicator for FFSB quality control and therefore, that NSI, PDI and PSKOH would be the preferred methods. Batal et al. (2000) reported that the PDI displayed the most constant response to the heating of FFSBs, while Dudley-Cash (2001) stated that the PDI may indicate soybean quality better than other indices. Therefore, the preference in this study has been given to the PDI method.

The aim of this study was to standardise, through an inter-laboratory study, the PDI method, to establish unit ranges for describing under-, adequate- and over-processed FFSB, as well as the precision of the method, i.e. values for its repeatability and reproducibility limits.

\section{Material and Methods}

Raw soybeans, as a mixture of cultivars with a moisture content of $100-110 \mathrm{~g} / \mathrm{kg}$, were processed by dry extrusion, using an industrial Insta-Pro 2000R" single-screw extruder at seven temperatures: 110, 127, $136,140,145,151$ and $164{ }^{\circ} \mathrm{C}$, with the processing time ranging between 30 and 40 seconds.

A total of 336 male Ross broilers were randomly allocated to 42 pens, each containing eight birds. On arrival, all broilers were sorted into equal weight groups, and assigned at random to the different treatment pens, such that the initial average weight and weight distribution were similar for all pens. They were allocated to one of seven dietary treatments containing a standard starter diet with the inclusion of the heattreated FFSBs, and with six replicates per treatment. The average body weight gain (ADWG) in the period from day 0 to day 14 and feed conversion ratio (FCR) on day 14 was monitored as production parameters. The protocol was approved by the ARC-Irene Animal Ethics Committee to ensure that it complies with South African and International standards for the care and use of animals for experimental purposes.

Seven samples of FFSBs, used in the in vivo trial with chickens, were analysed in duplicate by eight laboratories on the PDI. The laboratories were both commercial and research, and were all located in South Africa.

The PDI method (AOCS Official Methods, 1997a) has been subjected to an inter-laboratory study, which has been conducted strictly according to the "Collaborative Study Procedures" (AOCS Official Methods, 1997b).

For adequately-processed soybeans the globally-accepted values for PDI are between $15 \%$ and $28 \%$ (Monary, 1989), but in the description of the PDI method (AOCS Official Methods, 1997a) no values are specified. This fact provided an additional justification for the need to determine these PDI values through inter-laboratory analysis.

For FFSB protein dispersion, the PDI method uses a blender at a speed of $8500 \mathrm{rpm}$, which makes this method potentially the quickest and simplest to perform of all the methods for processed FFSB quality control. The "Hamilton Beach Commercial" blender, model G936 ("Vos Instrumenten", The Netherlands), is designed according to the PDI AOCS Official Method (1997a), but it was not available to all eight laboratories. It was, therefore, replaced by a "Warring Commercial" blender, model LB20E, which was calibrated against a "Hamilton Beach" blender to achieve the same PDI values. Consequently, the speed of the "Warring Commercial" blender was set at $12000 \mathrm{rpm}$.

The analytical procedure involved the blending of $20 \mathrm{~g}$ of sample with $0.3 \mathrm{dm}^{3}$ of water for exactly 10 min, followed by filtration of the slurry. Crude protein was determined in the supernatant and in the original soybean sample. The PDI was calculated as the ratio of soluble protein in the supernatant and total protein in the original FFSB sample.

Data were analyzed using the statistical program, SAS/STAT (1989). Analysis of variance (ANOVA) was used to test for differences between treatments. Treatment means were separated by using Fishers' protected t-test least significant difference (LSD) at the 5\% level of significance. The precision of the PDI method was determined according to the AOCS Official method (1997c).

\section{Results}

The results of the broiler trial are shown in Table 1. The best performance was achieved by chickens that were fed the FFSB processed at $136{ }^{\circ} \mathrm{C}, 140{ }^{\circ} \mathrm{C}$ and $145{ }^{\circ} \mathrm{C}$, and there was no significant difference between them $(P>0.05)$. However, the difference between the groups that received the FFSBs processed at $127^{\circ} \mathrm{C}$ and $136^{\circ} \mathrm{C}$, as well as at $145^{\circ} \mathrm{C}$ and $151^{\circ} \mathrm{C}$, was significant $(P<0.05)$. Based on these parameters, a relation between the temperature of extruding and the in vivo assessment of the degree of FFSB processing has been derived and is shown in Table 2 . 
Table 1 Means of average daily weight gain (ADWG) in the period from day 0 to day 14 and feed conversion ratio (FCR) at day 14, of broiler chickens fed full-fat soybean (FFSB) processed by dry extrusion at different temperatures

\begin{tabular}{|c|c|c|}
\hline Treatment & ADWG $(\mathrm{g})$ & FCR \\
\hline $110^{\circ} \mathrm{C}$ & $87.8^{\mathrm{bc}}$ & $2.081^{\mathrm{d}}$ \\
\hline $120^{\circ} \mathrm{C}$ & $96.0^{\mathrm{bc}}$ & $1.893^{\mathrm{cd}}$ \\
\hline $127^{\circ} \mathrm{C}$ & $108.0^{\mathrm{bc}}$ & $1.768^{c}$ \\
\hline $136^{\circ} \mathrm{C}$ & $138.3^{\mathrm{a}}$ & $1.382^{\mathrm{a}}$ \\
\hline $140^{\circ} \mathrm{C}$ & $132.0^{\mathrm{a}}$ & $1.466^{\mathrm{a}}$ \\
\hline $145^{\circ} \mathrm{C}$ & $123.0^{\mathrm{a}}$ & $1.529^{\mathrm{a}}$ \\
\hline $151^{\circ} \mathrm{C}$ & $97.2^{\mathrm{b}}$ & $1.679^{c}$ \\
\hline $164^{\circ} \mathrm{C}$ & $79.8^{\mathrm{c}}$ & $1.891^{\mathrm{cd}}$ \\
\hline
\end{tabular}

Table 2 Relation between the temperature of extruding and the in vivo assessment of the degree of full-fat soybean (FFSB) processing

\begin{tabular}{lc}
\hline Degree of FFSB processing & Temperature of extrusion $\left({ }^{\circ} \mathrm{C}\right)$ \\
\hline Under-processed & $<136$ \\
Adequately-processed & $136-145$ \\
Over-processed & $>145$ \\
\hline
\end{tabular}

It has been concluded that $136{ }^{\circ} \mathrm{C}$ and $145^{\circ} \mathrm{C}$ are the borders of the temperature range for adequatelyprocessed FFSB. The average values of the PDI in FFSB samples, analysed by eight laboratories, are shown in Table 3. It can be noted that the highest standard deviation was obtained for under-processed samples (110 and $\left.127^{\circ} \mathrm{C}\right)$.

Table 3 Average values of the protein dispersibility index (PDI) in full-fat soybean (FFSB) samples processed by dry extrusion at different temperatures

\begin{tabular}{crrrrrrr}
\hline \multirow{2}{*}{ Lab. no. } & \multicolumn{7}{c}{${ }^{1} \mathrm{PDI}(\%)$ at processing temperatures } \\
\cline { 2 - 8 } & $110^{\circ} \mathrm{C}$ & $127^{\circ} \mathrm{C}$ & $136{ }^{\circ} \mathrm{C}$ & $140^{\circ} \mathrm{C}$ & $145^{\circ} \mathrm{C}$ & $151{ }^{\circ} \mathrm{C}$ & $164{ }^{\circ} \mathrm{C}$ \\
\hline & & & & & & & \\
1 & 37.44 & 23.94 & 10.42 & 10.11 & 8.66 & 7.54 & 6.48 \\
2 & 36.71 & 21.39 & 10.18 & 9.17 & 8.78 & 7.54 & 6.42 \\
3 & 47.41 & 27.30 & 9.83 & 8.64 & 9.09 & 7.04 & 4.16 \\
4 & 46.57 & 30.60 & 12.67 & 9.69 & 8.98 & 4.27 & 2.03 \\
5 & 46.56 & 19.00 & 12.21 & 9.53 & 9.99 & 8.36 & 8.52 \\
6 & 45.93 & 28.19 & 10.18 & 9.02 & 8.86 & 8.56 & 7.94 \\
7 & 41.85 & 25.33 & 10.40 & 8.75 & 8.35 & 8.05 & 7.15 \\
8 & 36.33 & 12.05 & 6.48 & 6.50 & 5.22 & 5.11 & 5.03 \\
$\mathrm{SD}$ & 4.79 & 5.79 & 2.00 & 1.17 & 1.37 & 1.53 & 2.08 \\
& & & & & & &
\end{tabular}

${ }^{1}$ Average of two replicates; SD - Standard deviation. 
The influence of the temperature of processing on the PDI values is shown on Figure 1. A very high correlation $\left(\mathrm{R}^{2}=0.99\right)$ existed between the PDI values and the treatment temperature.

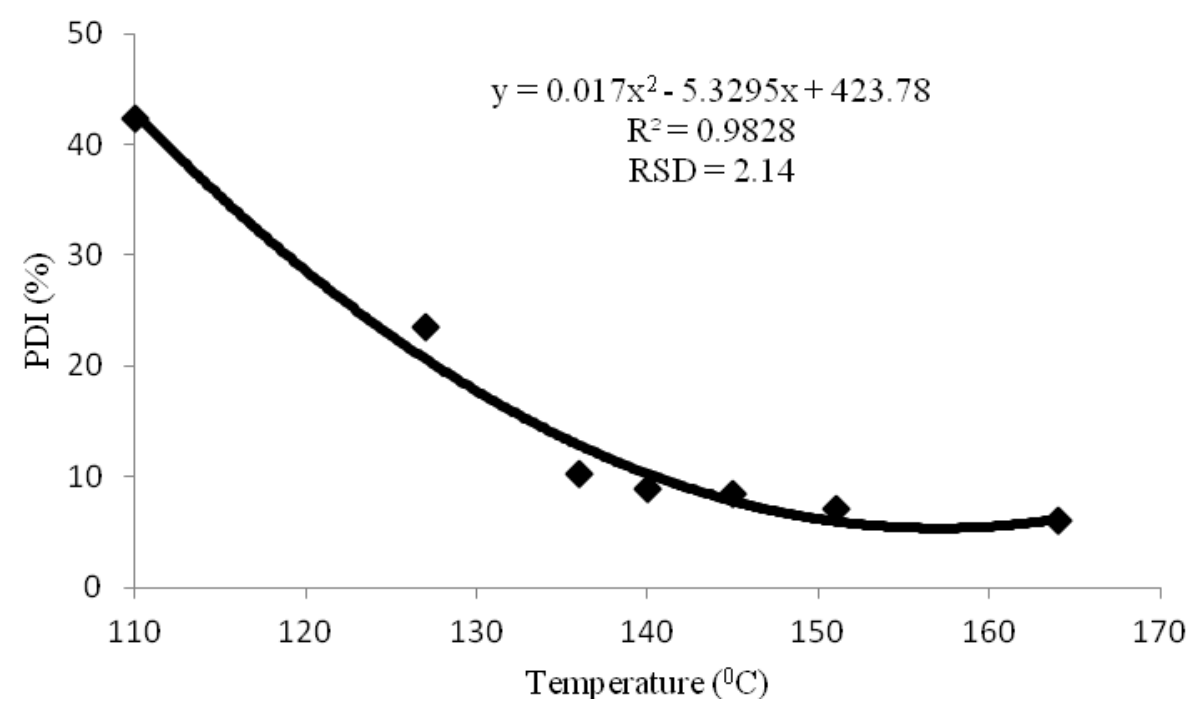

Figure 1 Correlation between the processing temperature and the protein dispersibility index (PDI) values.

The FFSB samples which were processed at temperatures between $136{ }^{\circ} \mathrm{C}$ and $145{ }^{\circ} \mathrm{C}$, represented adequately-processed FFSBs (Table 1). The PDI values for these samples obtained in the inter-laboratory study and shown in Table 3, were $10.3 \%$ and $8.5 \%$, respectively. Consequently, the PDI values shown in Table 4, for describing the degree of FFSB processing using the project PDI method, have been established.

Table 4 Protein dispersibility index (PDI) values for describing the degree of full-fat soybean (FFSB) processing, using the PDI method

\begin{tabular}{lc}
\hline Degree of FFSB processing & PDI (\%) \\
\hline Under-processed & $>10.3$ \\
Adequately-processed & $8.5-10.3$ \\
Over-processed & $<8.5$ \\
\hline
\end{tabular}

The PDI range for adequately-processed FFSB was between 8.5 and $10.3 \%$. PDI values above $10.3 \%$ corresponded with the under-processed, whereas the values below $8.5 \%$ corresponded with the overprocessed FFSB.

The precision parameters of the PDI method are shown in Table 5. The results obtained under the conditions of this study showed that the repeatability limit (r), i.e. the absolute difference between two single results of analysis of the same sample obtained in one laboratory, should not exceed $2.1 \%$. It was found that the reproducibility limit (R) of the PDI method, i.e. the absolute difference between single results of analysis of the same sample obtained in different laboratories, should not exceed $7.73 \%$. 
Table 5 Precision parameters of the protein dispersibility index (PDI) method

\begin{tabular}{|c|c|c|c|c|c|c|c|c|}
\hline \multirow{2}{*}{ Parameter } & \multicolumn{7}{|c|}{ Sample according to heat treatment } & \multirow{2}{*}{$\begin{array}{c}\text { Average } \\
\text { values }\end{array}$} \\
\hline & $110^{\circ} \mathrm{C}$ & $127^{\circ} \mathrm{C}$ & $136^{\circ} \mathrm{C}$ & $140^{\circ} \mathrm{C}$ & $145^{\circ} \mathrm{C}$ & $151^{\circ} \mathrm{C}$ & $164^{\circ} \mathrm{C}$ & \\
\hline Number of laboratories & 8 & 8 & 8 & 8 & 8 & 8 & 8 & \\
\hline $\begin{array}{l}\text { Number of laboratories retained } \\
\text { after eliminating outliers }\end{array}$ & 8 & 8 & 8 & 8 & 8 & 8 & 8 & \\
\hline $\begin{array}{l}\text { PDI mean values ( } \%) \text {, average } \\
\text { for eight laboratories }\end{array}$ & 42.3 & 23.4 & 10.3 & 8.9 & 8.4 & 7.0 & 5.9 & \\
\hline $\begin{array}{l}\text { Repeatability standard } \\
\text { deviation }\left(\mathrm{s}_{\mathrm{r}}\right), \%\end{array}$ & 1.20 & 1.15 & 1.21 & 0.67 & 0.27 & 0.37 & 0.36 & 0.75 \\
\hline $\begin{array}{l}\text { Repeatability relative standard } \\
\text { deviation }\left(\mathrm{RSD}_{\mathrm{r}}\right), \%\end{array}$ & 2.85 & 4.92 & 11.80 & 7.60 & 3.22 & 5.33 & 6.09 & 4.94 \\
\hline $\begin{array}{l}\text { Repeatability limit (r) } \\
{\left[\mathrm{r}=2,8 \times \mathrm{x}_{\mathrm{r}}\right], \%}\end{array}$ & 3.38 & 3.23 & 3.40 & 1.90 & 0.76 & 1.05 & 1.01 & 2.10 \\
\hline $\begin{array}{l}\text { Reproducibility standard } \\
\text { deviation }\left(s_{R}\right), \%\end{array}$ & 4.94 & 5.98 & 2.04 & 1.19 & 1.41 & 1.58 & 2.15 & 2.76 \\
\hline $\begin{array}{l}\text { Reproducibility relative } \\
\text { standard deviation }\left(\mathrm{RSD}_{\mathrm{R}}\right), \%\end{array}$ & 11.7 & 25.5 & 19.9 & 13.4 & 16.7 & 22.4 & 36.1 & 18.1 \\
\hline $\begin{array}{l}\text { Reproducibility limit }(\mathrm{R}) \\
{\left[\mathrm{R}=2,8 \times \mathrm{s}_{\mathrm{R}}\right], \%}\end{array}$ & 13.9 & 16.8 & 5.7 & 3.4 & 4.0 & 4.4 & 6.0 & 7.7 \\
\hline
\end{tabular}

\section{Discussion}

According to the in vivo trial with broilers (Table 1), the samples which represent adequatelyprocessed FFSBs were heat-treated at $136{ }^{\circ} \mathrm{C}$ to $145{ }^{\circ} \mathrm{C}$. The PDI values for those temperatures were between $8.49 \%$ and $10.30 \%$. Nevertheless, these results are much lower than the globally-accepted PDI values which are between 15\% and 28\% (Monary, 1989). At this stage, there is no firm explanation for the difference between the globally-accepted values and the values established in the present study.

There was a good correlation between the PDI values and extrusion temperatures. Studies by Lee et al. (2007) also reported a good correlation between the treatment temperatures and PDI values. The present study showed that there was a steep decrease in the PDI from a temperature of $110^{\circ} \mathrm{C}$ to $127^{\circ} \mathrm{C}$ and, thereafter, a slight decrease was observed throughout. Batal et al. (2000) reported a consistent pattern of decrease in the PDI in response to the temperature.

The results of the present study on the precision of the PDI method, showed that two single determinations performed in one laboratory should not differ by more than $2.1 \%$, whereas two single determinations performed in different laboratories should not differ by more than $7.73 \%$. This is in line with the precision parameters presented in the PDI AOCS Official Method (1997a), which for repeatability and reproducibility limits stated $4.37 \%$ and $9.66 \%$, respectively. The repeatability limit of $2.1 \%$ for the PDI method was very good. Nevertheless, the reproducibility value of $7.73 \%$ was too broad considering the narrow range $(8.49-10.30 \%)$ for adequately-processed FFSBs, which creates a concern with regard to the use of the PDI method in practice.

The optimum temperature for the dry extrusion of full-fat soybeans for use in poultry feeding in this study was between $136^{\circ} \mathrm{C}$ and $145^{\circ} \mathrm{C}$. This is in line with the results of Ruiz et al. (2004) who established, in a trial with broilers fed extruded FFSBs, that body weight gain and FCR were best for treatment temperatures between $126^{\circ} \mathrm{C}$ and $140{ }^{\circ} \mathrm{C}$. Nelson et al. (1987) stated that temperatures most commonly used commercially for extruding raw soybeans were between approximately $135{ }^{\circ} \mathrm{C}$ and $140{ }^{\circ} \mathrm{C}$. Palic et al. (2009) concluded from two separate trials with broilers that the optimum heat treatment of FFSBs was at $138^{\circ} \mathrm{C}$ and $144^{\circ} \mathrm{C}$.

Despite reports (Batal et al., 2000; Dudley-Cash, 2001; Debruyne, 2004; Caprita et al., 2010a; b) on the dominance of the PDI over other methods for monitoring the degree of FFSB heat treatment, the PDI method did not prove that in this study. It is to be noted that the above-mentioned authors obtained their 
results in single laboratory studies, contrary to the present study, which might be the explanation for the differences in results.

\section{Conclusions}

Despite its simplicity and initial indications that it might be the best indicator of FFSB processing, the protein dispersibility index did not prove that in this inter-laboratory study. The analysis of FFSBs by the PDI method generated adequately-processed FFSB values between $8.49 \%$ and $10.30 \%$. Values above $10.30 \%$ described under-processed and values below $8.49 \%$ described over-processed FFSBs. The PDI method generated a good repeatability limit of $2.1 \%$, but the reproducibility limit $(7.73 \%)$ was too wide, taking into account the narrow range $(8.5-10.3 \%)$ for adequately heat-treated FFSBs. Based on the results of this inter-laboratory study, the PDI method cannot be recommended as a reliable indicator of quality control for heat-processed FFSBs, or for use in routine laboratory practice.

\section{Acknowledgement}

This study has been supported by the Protein Research Foundation of South Africa.

\section{References}

AOCS Official Methods, 1997a. Sampling and Analysis of Oilseed By-products, Protein Dispersibility Index, AOCS Official Method Ba 11-65.

AOCS Official Methods, 1997b. Collaborative Study Procedures, AOCS Procedure M 4-86.

AOCS Official Methods, 1997c. Determination of Precision of Analytical Methods, AOCS procedure M $1-92$.

Batal, A.B., Douglas, M.W., Engram, A.E. \& Parsons, C.M., 2000. Protein dispersibility index as an indicator of adequately processed soybean meal. Poult. Sci. 79, 1592-1596.

Buttle, L.G., Burrells, A.C., Good, J.E., Williams, P.D., Southgate, P.J. \& Burrells, C., 2001. The binding of soybean agglutinin (SBA) to the intestinal epithelium of Atlantic salmon, Salmo salar and Rainbow trout, Oncorhynchus mykiss, fed high levels of soybean meal. J. Vet. Immun. Immunopath. 80, 237-244.

Caprita, R., Caprita A., Gheorghe, I., Cretescu, I., Simulesku, V.O., 2010a. Laboratory procedures for assessing quality of soybean meal. Proc. World Congress on Engineering and Computer Science, WCECS 2010, vol. II, October 20-22, San Francisco, USA.

Caprita, R., Caprita, A. \& Cretescu, I., 2010b. Protein solubility as quality index for processed soybean. Anim. Sci. Biotechnol. 43, 375-378.

Davies, H., 1998. Manufacturing of full-fat soybeans. Proc. Workshop: Processing of full-fat soya, 12 March, Irene, South Africa. pp. 21-23.

Debruyne, I., 2004. Protein despersibility index: Best option to evaluate SBM for poultry. Feed International, July 2004, 10-12.

Dudley-Cash, W.A., 2001. PDI may better indicate soybean meal quality than other indices. Feedstuffs 73 (1), 10-11.

Lee, H.S., Kim, J.G., Shin, Y.W., Park, Y.H., You, S.K., Kim, S.H. \& Whang, K.Y., 2007. Comparison of laboratory analytical values and in vivo soybean meal quality on pigs by employing soyflakes heattreated under different conditions. Anim. Feed Sci. Technol. 134, 337-346.

Monary, S., 1989. Full-fat Soya Handbook, $2^{\text {nd }}$ ed., American Soybean Association, Brussels, Belgium. pp. 22-28.

Nelson, A.I., Wijeratne, W.B., Weh, S.W., Wei, T.M. \& Wei, L.S., 1987. Dry extrusion as an aid to mechanical expelling of oil from soybeans. J. Am. Oil Chem. Soc. 64, 1341-1347.

Palacios, M.F., Easter, R.A., Soltwedel, K.T., Parsons, C.M., Douglas, T., Hymowitz, M.W. \& Pettigrew, J.E., 2004. Effect of soybean variety and processing on growth performance of young chicks and pigs. J. Anim. Sci. 82, 1108-1114.

Palic, D. \& Grove, A.A., 2004. Validation of methods for determining the degree of soya processing: preliminary study. Joint GSSA - SASAS Congress, 28 June - 1 July, Goudini Spa, South Africa. Book of abstracts. p. 181. 
Palic, D., Moloto, K., Coetzee, S.E. \& Djuragic, O., 2007. Critical assessment of laboratory methods for full -fat soybean quality control. Proc. $1^{\text {st }}$ International Congress on Food Technology, Quality and Safety, 13 - 15 November, Novi Sad, Serbia. pp. 197-202.

Palic, D., Siebrits, F.K. \& Coetzee, S.E., 2009. Determining the optimum temperature for dry extrusion of full-fat soybeans, S. Afr. J. Anim. Sci. 39 (Supplement 1), 69-72.

Palić, D., Morey, L, Modika, K.Y., Kokić, B., Djuragić, O. \& Spasevski, N., 2011. Precision of laboratory methods based on protein solubility in quality control of heat treated feedstuffs. Chem. Industry, doi:10.2298/HEMIND110623054P.

Ruiz, N., De Belalcazar, F. \& Diaz, G.J., 2004. Quality control parameters for commercial full-fat soybeans processed by two different methods and fed to broilers. J. Appl. Poult. Res. 13, 443-450.

SAS/STAT, 1989. Statistical Analysis Systems, User's Guide, Version 6, 4th ed. SASAS Institute Inc., Volume 2, Cary, N.C., USA.

Vasconcelos, I.M., Maia, A.A.B., Siebra, E.A., Oliveira, J.T.A., Carvalho, A.F.F.U., Melo, V.M.M., Carlini, C.R. \& Castelar, L.I.M., 2001. Nutritional study of two Brazilian soybean (Glycine max) cultivars differing in the contents of anti-nutritional and toxic proteins. J. Nutr. Biochem. 12, 1-8.

Vohra, F. \& Kratzer, F.K., 1991. Evaluation of soybean meal determines adequacy of heat treatment. Feedstuffs 63 (8), 22-25. 